\title{
Discourses of Inverted Yield Curve and the Reaction on US Stock Markets
}

\author{
M Akhsanur Rofi \\ Progam Studi Akuntansi Bisnis, Sekolah Tinggi Manajemen PPM \\ Jl. Menteng Raya No.9, Kb. Sirih, Kec. Menteng, Kota Jakarta Pusat, Jakarta, Indonesia \\ akhsanur@live.co.uk
}

Received: 09-02-2021

Accepted: 16-06-2021

Published: 30-06-2021

\begin{abstract}
ABSTRAK
Sebuah model prediktif pertumbuhan ekonomi sangatlah penting bagi pemerintah, institusi keuangan, korporasi, investor, hingga rumah tangga. Kurva imbal hasil terbalik atau inverted yield curve (IYC) adalah model prediksi resesi ekonomi yang sudah dipercaya sejak lama. Namun perkembangan saat ini mengindikasikan terdapat perubahan pola pada IYC yang dapat saja merupakan situasi normal baru yang terjadi di pasar keuangan, kekhawatiran investor berlebihan, atau hal lainnya. Hal ini memunculkan diskursus apakah model ini tetap reliabel atau tidak reliabel. Penelitian ini difokuskan pada analisis diskursus pemangku kepentingan di pasar keuangan Amerika Serikat dan bagaimana dampak rasional atau tidak rasional di pasar saham dengan menggunakan analisis jaringan diskursus, analisis grafik, dan analisis $t$-Test. Hasilnya menunjukkan bahwa memang terdapat perubahan pola pada IYC dan terdapat pergerakan pasar saham dalam jangka pendek mengikuti teori informasi.
\end{abstract}

Kata Kunci:

Inverted Yield Curve; Analisis Jaringan Diskursus; Pasar Keuangan; Pemodelan; Teori Informasi

\begin{abstract}
An outlook model to predict future economic growth is crucially important for government, financial institution, corporate, investor, as well as household. An inverted yield curve has been trusted for long time as a prediction for economic recession. But current development showed that there is change in IYC pattern that might be because of the new normal of market condition, anxious investor, or something else, hence it created the discourse among market stakeholder whether it remain a reliable prediction model or not. The research will focus on discourse among important economic stakeholders in US market and how they might impact on stock market rationally or irrationally using discourses network analysis, graph analysis, and t-Test analysis. The result confirmed that there is a different pattern on IYC, also there is a short-term correlation between IYC and stock price movement, confirmed the information theory.
\end{abstract}

Keywords:

Inverted Yield Curve; Discourses Network Analysis; Financial Market; Modeling; Information Theory 


\section{INTRODUCTION}

In macroeconomics, the term spread which is the difference between long-term \& short-term interest rate - could occurred between rate in the money market and the rate in the debt market - is an important relationship to predict future economic activity (Madura, 2017). The understanding is based on the connection that interest rate move in accordance with investor expectation. Normally, the shortterm rate should go lower than long term rate as investor expected lower risk faced by current assets traded in the money market. In recession times, the relationship could drive the other way.

A possible explanation according to business cycle concept is the central bank will gradually raise short term interest rate during an economic expansion, but long-term rate will remain high. The latter rate will be lowered if investor becomes more pessimistic thus shape a flatter yield curve in the bond market. The short-term rate even higher if the market liquidity shifted from money market to capital market, as it less profitable to borrow in short- term and lend in long-term, reduce loan supply and tighten credit condition. The inverted yield curve is created and, in most times, precede economic recession (Nations, 2017).

A statistical analysis of inverted yield curve in the past 60 years was always followed by economic slowdown, even though there is a delay for 6 to 24 months from negative spread into beginning of a recession, it reliably predicts the future economic activity (Bauer \& Mertens, 2018). Different observation might argue that historical experiences do not necessarily apply into any situation, as the current central bank's economic policy tend to relatively lower long-term rates hence acted as the new normal rather than reflected as a grim outlook (Bauer \& Rudebusch, 2014).

Below is picture of Holston-Laubach-Williams model that provide estimation of short-term interest rate when advanced economy in the US, Canada, Euro Area, and UK are at full strength and inflation is stable (Holston, Laubach, \& Williams, 2017). As shown below, the R-star prediction model maintained an accurate prediction from year 1985, but since 2010 there is a greater deviation as economic growth tend to stable at $1.5 \%$. The picture hint that there might be different the relationship between interest rate-trend growth nowadays.

The discourse is increasing to a divided debate whether an inverted yield curve is an early warning of bad economic outlook or rather just the new normal. It is also having a big impact on investor expectation as it creates uncertainty, market turmoil, and panic over the short-term and longterm. The research focusses on this paper is to examine the discourses of important economic stakeholders during the arising of inverted yield curve in the United States especially in the event of US bond market in the last two years that might generate substantial information of market behavior and create significant movement in several US major markets accordingly. 


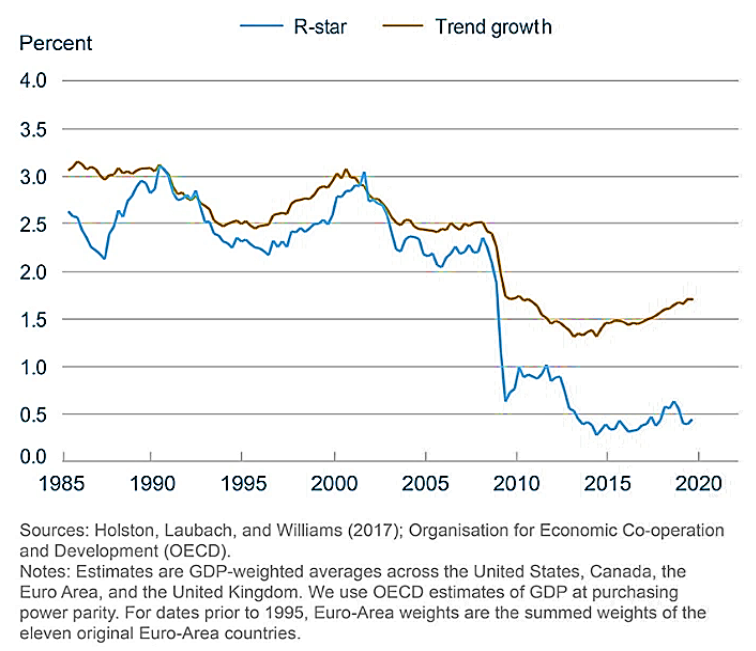

Figure 1. The R-Star as Real Short-Term Interest Rate from 1985 to 2017 Source: (Holston, Laubach, \& Williams, 2017)

\section{Yield Curve}

The term yield curve is a graph reference in the financial market shows the yield of relatively fixed-interest securities plotted against time to maturity. While the bond market (or credit market) is a marketplace for the lender and the borrower of money, its balance of demand - supply will created such term maturity with shorter term should be expected normally lower rate than longer term therefore would visuallyproduce an exponential or logarithmic curve, correlated with expected inherence risk between short term asset and long-term asset as well a makeup for locking money up for a greater period. In contrast, bonds that oblige investors to make shorter time commitments, such as for 3 months, do not involve as much sacrifice hence will pay less rate (Bodie, Kane,\& Marcus, 2013).

It should be note that the yield curve would dynamically change as the lender \& borrower should perceive economic growth. Financial analyst typically focuses on three months, or one to twoyears Treasury yield as an indicator of monetary policy set by central bank, while use 10-years Treasury Bond as long-term investor's perception and sentiment in the bond market (Bauer \& Merten, 2018). A healthy economic condition will keep term maturity balanced and ideal. But once a slowdown in the economy spotted such as slower manufacturing index, it could turn into growing concern among investors and economic stakeholders. The possible impact include change of liquidity in the market since investor might shifted their asset from short-term into long-term as a response to protect, avoid, or hedge any possible negative gain, risks, or higher cost during slowdown (Bloomberg, 2018). An aggregate response could trigger more expensive long-term asset price, lowered long term yield hence developed an IYC, created negative spread, then dried the already difficult short-term market, infused more pressure in the real economy that in great need for money to drive consumption and lower cost of capital. 


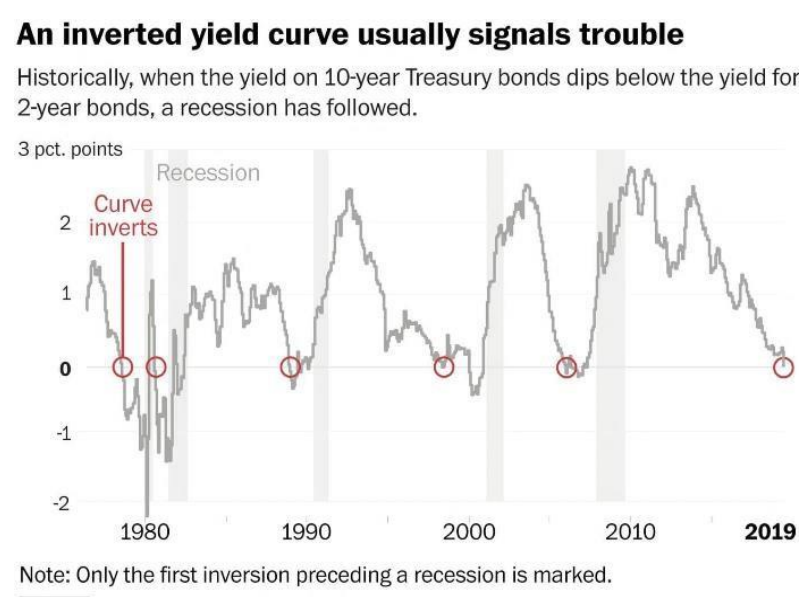

Figure 2. Recent Negative Spread before Recession Source: $(F T, 2019) \&$ (Marte, 2019)

As shown in figure 2, a higher short-term rate would cause higher short-term cost of capital, and could cause negative spread, then illustratively precede the four recession during 1980 - 2010. The recent negative spread in 2019 once again created fear to millions of investors from individual savers to money manager to leading market forecaster. It also a reason to worry for banks, corporate, as well individual borrowers such as mortgage owner and retail credit user. Most economic experts expect the central bank to fix the high cost of obtaining credit by changing their economic policy (Bloomberg, 2019).

\section{Discourses of Inverted Yield Curve}

Despite longstanding reputation as an omen for recession, an inverted yield curve might be an artificial of lower long-term yield if pension funds and central banks bought vast quantities of bond. It also arisen when fears of global slowdown due to trade war have spurred huge capital movement from equities into bonds, which will also create lowered long-term yield. While there is no real sign in the real economy as US unemployment is low, inflation is stable, wage is rising, stock market as well as the economy continue to grow (Smith, 2019).

In 2019, an inverted yield curve already appeared in March and August. But the conversation is heightened in later period as more market stakeholders begin to question how it will unfold in the future and why two consecutives inversion arose at the same years. Below is the recent inversion curve between 2- year Treasury and 10-year government bond.

Some market observation seen a distorted in yield curve was caused by huge foreign bondsmainly from Europe that pay negative interest rate. The rate that went below zero is perceived to be the new normal since central banks around the world unable to return interest rate to historically normal level after the great recession in 2008. Instead of panic, the brief inversion would only highlight of signal for caution, even it could generate some capital gain (Lewis, 2019), (duQuesnay, 2019). 


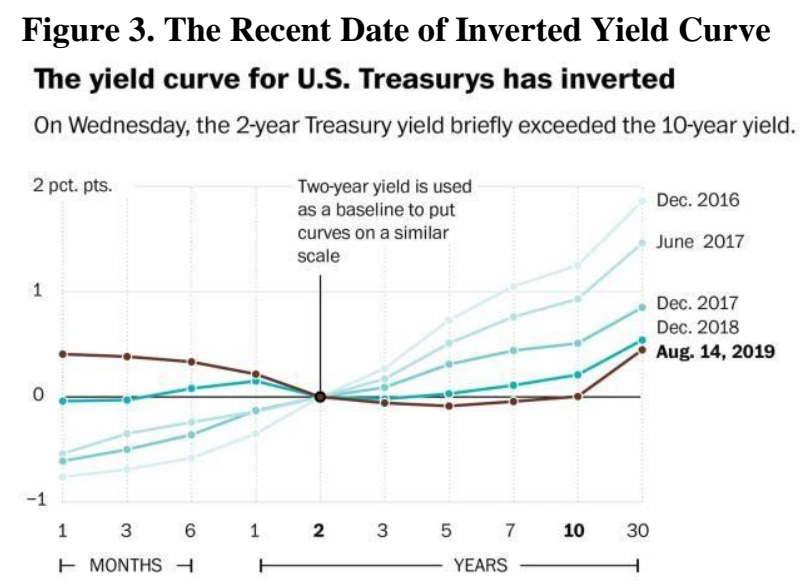

Sumber: Marte, 2019

Some investors would take a short-term profit while some others rather be careful to maintain their asset allocation. Such capital gain might be acquired in the longer-term bonds with highest credit quality should price of riskier assets and short-term bond yield both fall as a recession unfold and stock market volatility increases (Fidelity, 2019). Looking at last five negative spread, stocks could still enjoy an average gain until 15\% over those periods (O'Mahony, 2019).

Other reason why the discourses of inversion of yield curve unsettled is that not only the timing of recession after negative spread appeared is uncertain, but there is also a disagreement whether to use three-month Treasury yield or two-years Treasury yield. The danger of near- term recession might also claim to be overstated if it only happened at a very brief time, it needs to last for three months for a reliable recession signal. A more sceptic note would view inverted yield curve had better prediction in US only, less accurate at other advanced economies, even worse at emerging countries. Although the impact of inversion could diffuse into international markets other than US market economy.

Although there is an increased awareness of the yield curve's importance today, at first it was continuously ignored by Federal Reserve as US central bank. Thus, The Fed continued their policy of high rates after an inversion. Whilst now they noticed the curve and took different approach by cutting rates well ahead of recession signals make it less significance of the usefulness of inverted yield curve as predictor. Nevertheless, others would stand with their view to stay more cautious, cut back on spending, and further increasing the likelihood of recession (O'Mahony, 2019). As a conclusion, things are still uncertain. Hence, the first hypothesis is:

$\mathrm{H}_{01}$ : The IYC is not reliable for recession prediction. (Argument: No, Color: Red)

$\mathrm{H}_{1}$ : The IYC is reliable for recession prediction. (Argument: Yes, Color: Green)

\section{Information Theory}

According to (Chen, 2006), "Securities often experience cycles of underreaction and overreaction as the result of investors' information processing. What determine the level of underreaction and overreaction? It depends on how much we understand the fundamentals. If the fundamentals are easy to understand by many people, both initial underreaction and eventual 
overreaction will be small. If the fundamentals are difficult to understand, mispricing can be substantial." In contextual understanding of the information theory, the inverted yield curve provides some fundamental overview of future estimation of the economic growth. The worries of investors about future economy might create a substantiative movement in the market, whether in money market, stock market, debt market or derivative market. An extensive research is needed to cover all their cumulative reaction.

Previous application to use information theory on network science to analyze or predict stock market have been done by (Yoshinaga \& Junior, 2012), (Brida, Gomez, \& Seijas, 2015), (Wu, Tuo, \& Xiong, 2015), (Minjun \& Sayama, 2017). All those studies were using internal structure of stock network to derive behavioral pattern and statistical value that provide important information to analyze stock price movement.

In this research, an external network analysis of stakeholders' discussion is used to analyze whether their reaction about (a particular) information is substantiated in the stock market. By using simple approach of market reaction measured by the difference before and after IYC showed up. Assuming that investor is behave on their own, and market is not fully efficient, the second hypothesis is:

$H_{02}$ : There is no mean difference in stock price change between before and after IYC showed.

$\mathrm{H}_{2}$ : There is a mean difference in stock price change between before and after IYC showed.

\section{RESEARCH METHODS}

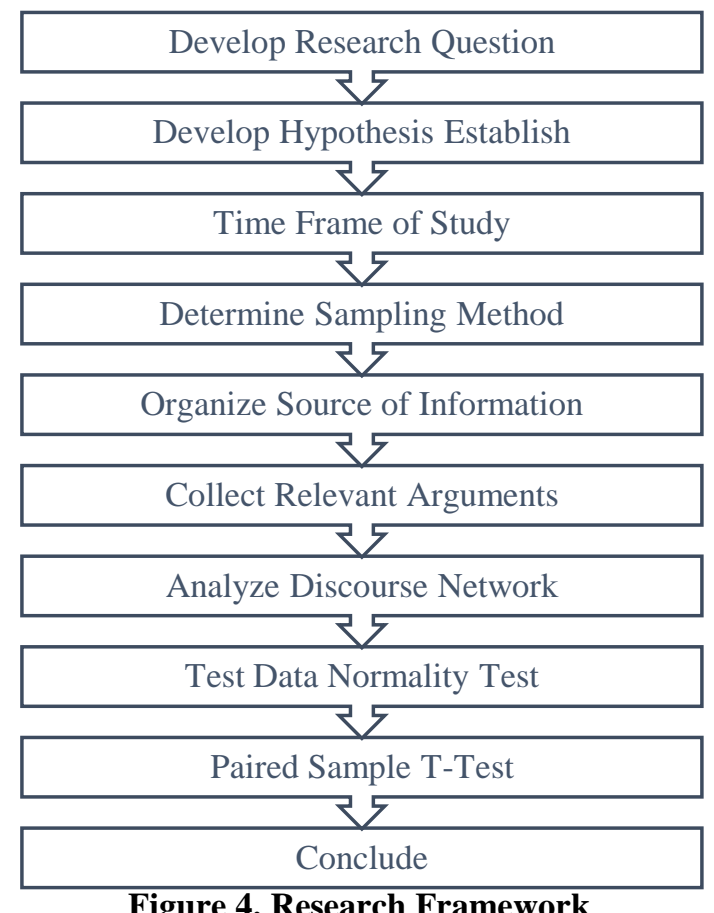

In Figure 4, the mixed method research framework is explained. The research takes the moment on the event of inversion presence on August $14^{\text {th }}, 2019$ of US bond market when it caused 
conversation trend among media, investors, and other economic stakeholders, mainly in US market. Then it compared to previous two times of IYC. As shown in Figure 5, the search queries of inverted yield curve in Google Search had been peaked at 100 of index scale from 0 to 100 on that date, much higher than in previous presence in March 2019 and December 2008.

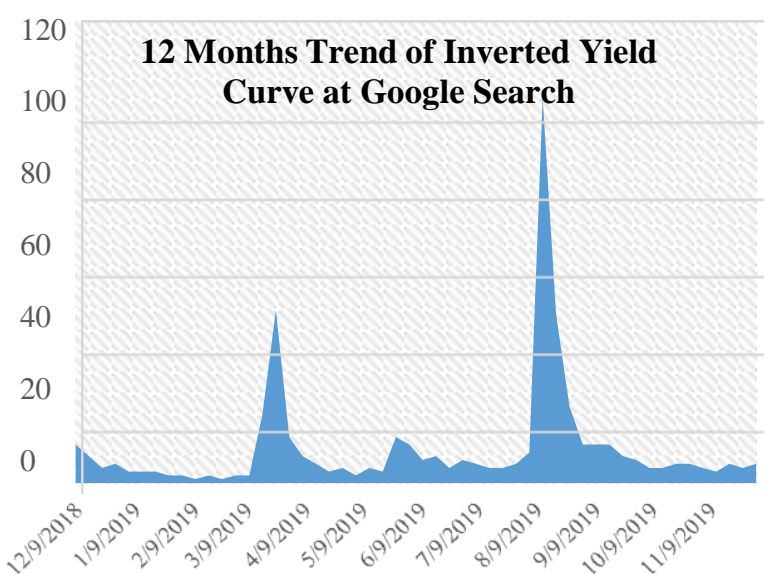

Figure 5. The Trend of Inverted Yield Curve (Marte, 2019)\

Based on timeframe of inverted yield curve, here is the timeline of study:

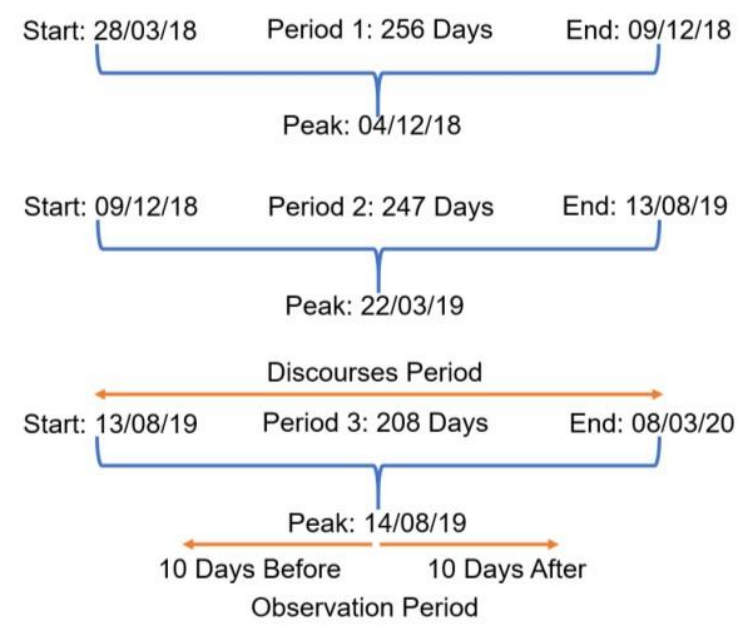

Figure 6. The Timeline of Study

The research question contains two problem that should be done by mixed method - at first a qualitative method using discourses network analysis (DNA) then a quantitative method using paired sample T-Test. The research design uses a constructivism view from (Creswell, 2009). He stated that the view will appropriate to gain and construct an understanding of social and historical phenomenon by extracting participants meaning thus subsequently might be possible to the development of new theory. Qualitative study of DNA is a phenomenology study using visualized content analysis with networks of important feature that contain information of research subjects explicitly and implicitly from which a substantial meaning should be developed.

There are three major economic stakeholders that situated as a research subject in terms of discourses in inverted yield curve. First, the government and Federal Reserve banks that positioned as 
regulator, the last resort on economic stability, as well as the market maker in terms of demand and supply money to the financial market.

Second is financial institution that served as financial market players who will respond any information on the market including yield curve and will act heterogeneously according to their own perception regarding to that information. While their movement in aggregate can be viewed through price change in several major indices.

Third is mass \& media which include economic expert, analyst, market forecaster, academics and mass opinion that create a unique environment comprises of mass emotion, shared feeling, sentiment, as well as public attitude which formed rational and irrational behavior as well as emotional contagion. The mass \& media comes from media companies, research/education institutions, \& association.

In DNA research design, the goal is to capture most conversation on the same topic, hence the population is all global news media. But the reliable, trusted global news media is somewhat arbitrary (Marquit, 2019). Narrowing down to a manageable sampling work, the purposive method is used, the criteria must be: (1) Online news that accessible at time chosen for study: March 28, 2018 until March 3, 2020, (2) Indexed news at Google Search until page 30 for keyword of Inverted Yield Curve during the time of study, (3) Actors from sources represent three stakeholders: US government, financial services company, and mass \& media. The goal is to cover information as much as possible and to minimize the reliability issue.

Before developing into network, the discourses concept of inverted yield curve is constructed based on all cited arguments of all collected sources. Every argument is extracted then form into several categorizations based on context similarity, keyword similarity, \& most frequent citation.

Here is the list of concepts: (1) After inversion, there are some time and ways before recession, (2) Inversion is the new normal due to the Fed policy, (3) Inversion makes investors worried hence contribute to the upcoming recession, (4) Not only inversion, but other predictor should also show if there is a recession, (5) Several factors make inversion unreliable for predictor, (6) There are evidence for inversion as a recession forecast.

After concept is developed, Argument 'No' will be placed to each concept that perceived by actors as not a reliable predictor. While Argument 'Yes' will be placed if the concept is perceived as a reliable predictor by actors. Here is the summary of sample data for qualitative research (Table 1).

The process after creating the discourses network for all periods, is to develop the quantitative aspect to examine information theory. Assuming the day when IYC was emerged is the most important issue faced by investors and other stakeholders, hence the market movement can be interpreted based on that information.

Investors will respond proportionally according to the information in accumulative way hence their movement could be read on stock index. Using paired sample T-Test, the difference in sample 
means before and after IYC emerged can be interpreted as a reaction from investors, though it might not be able to analyze whether those reaction is underreaction or overreaction.

Table 1. Summary of Sample Data for Discourses Network

\begin{tabular}{cc}
\hline Characteristics & Amount \\
\hline Concepts & 6 \\
Arguments & 342 \\
Argument No & 172 \\
Argument Yes & 169 \\
Actors & 184 \\
Specified & 176 \\
Anonymous & 8 \\
Organizations & 129 \\
Financial Services & 70 \\
Government & 12 \\
Media & 28 \\
Research/Education & 17 \\
Association & 2 \\
\hline Sources: Author Data Processing Results
\end{tabular}

The observation period is 10 days or two weeks in trading day (before and after IYC emerged) as the longest estimated term for investors reaction as well as to obtain data normality. Observing only 1 days might be too short or five days might not cover all reaction. Furthermore, the analysis will include normality test using Kolmogorov Smirnov Test (KS), where if calculated-KS < Table-KS, then the decision is the data is normally distributed. Conversely, if calculated-KS > Table-KS, then the data is not normal. Other classic assumption test such as heteroscedasticity, autocorrelation, or multicollinearity test are not applied in this research.

Hypothetically, a prediction for recession can cause market to move down or to enter bear market. Analysis price change will be focused on US major stock market index such as Dow Jones (DJI), NASDAQ (GSPC), and S\&P 500 (IXIC).

\section{RESEARCH RESULT AND DISCUSSION}

Figure 7,8,9 below are the results of discourses network in three period. While Period 1 is taking longest time frame compared to other, it seems that it created the less dense network. On the other hand, Period 3 is the shortest period but also the densest network. 


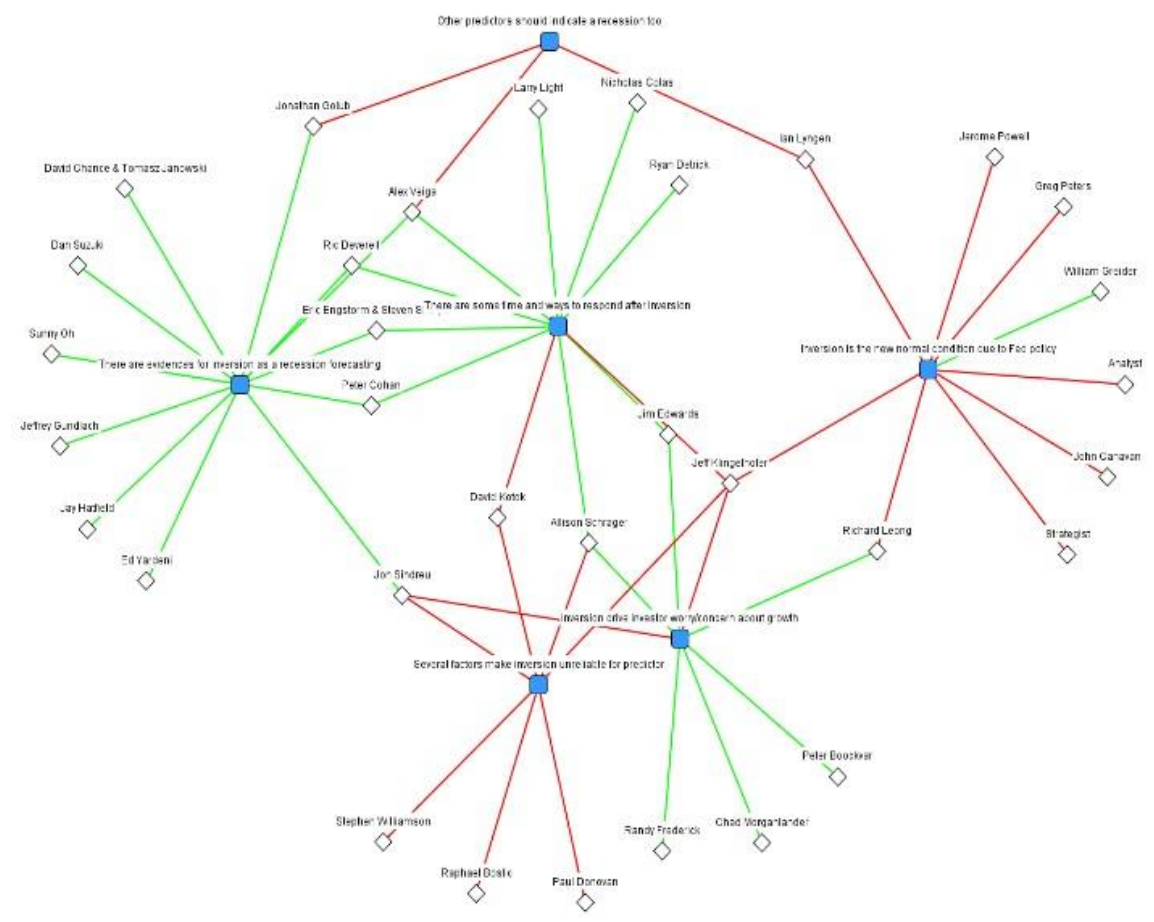

Figure 7. Affiliation Network of IYC at Period 28 March - 9 December 2018 (Actor mode)

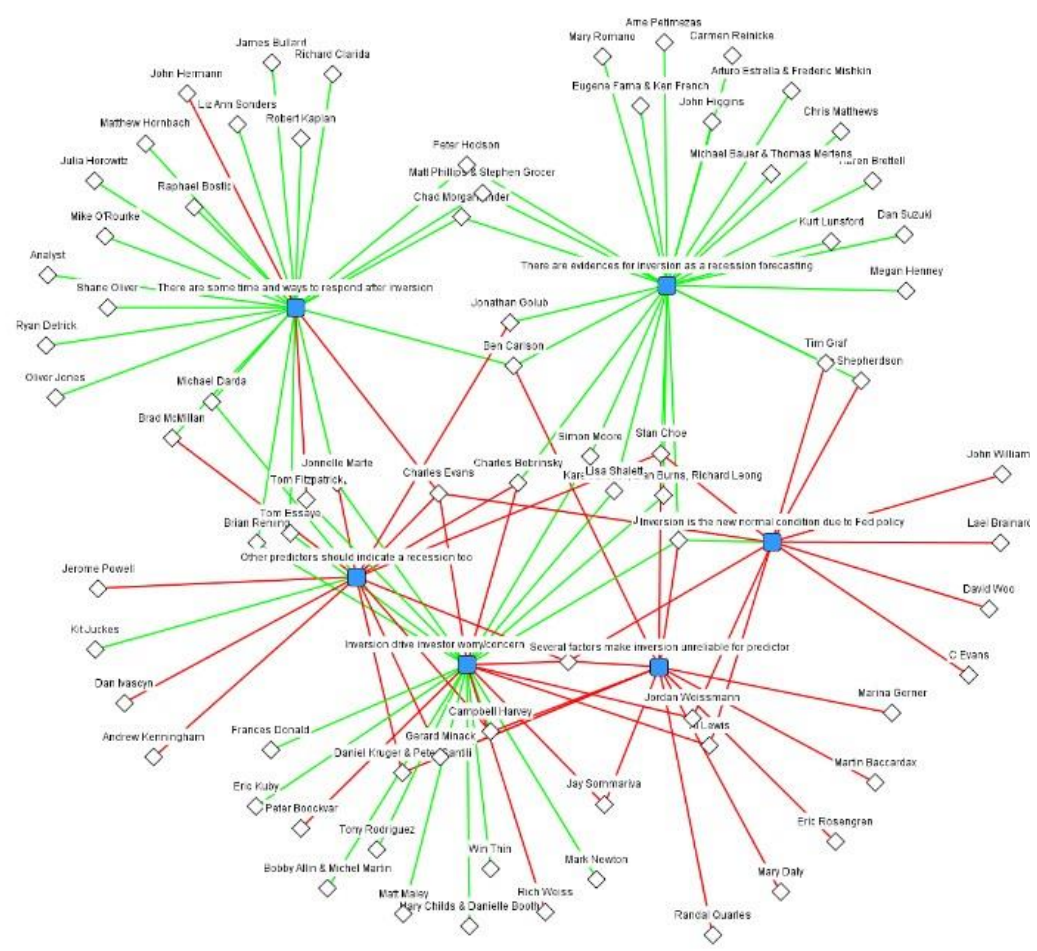

Figure 8. Affiliation Network of IYC at Period 9 December 2018 - 13 August 2019 (Actor mode) 


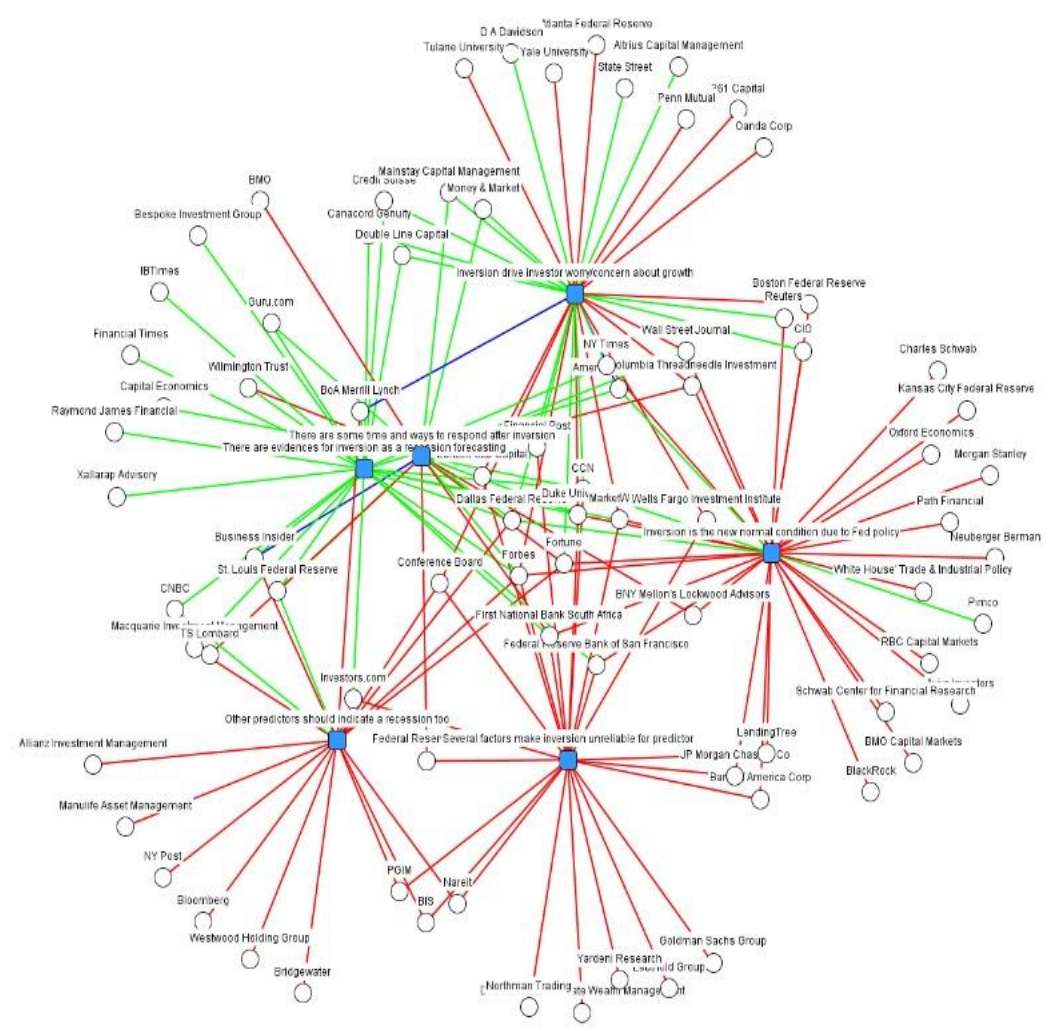

Figure 9. Affiliation Network of IYC at Period 13 August 2019 - 8 March 2020 (Organization mode)

Analyzing through different time by splitting information into 3 period as shown in Figure 7, 8 , and 9 , it found that the conversation grew bigger as time went by. However, the concept was the same amount, which means that the argument was not changed or developed, only drew more people and organization, and more intense and ambiguous conversation. The blue line in Period 3 showed that the same actors said 'Yes' and 'No' at the same time.

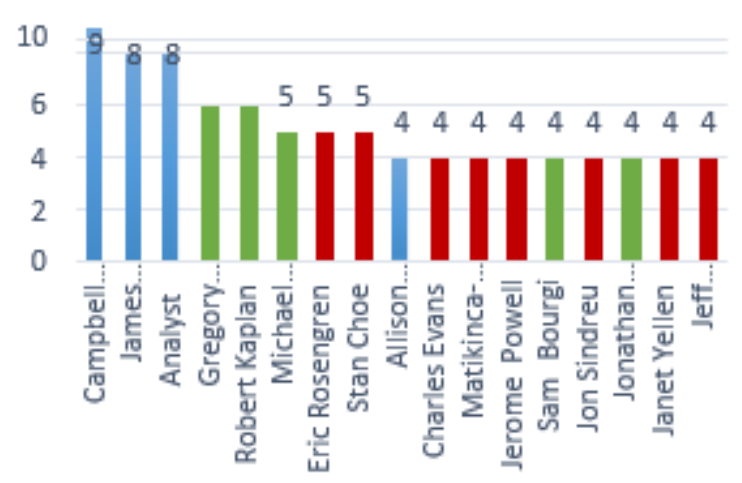

Figure 10. Most Vocal and/or Most Cited Actors

(Colored argument, Blue: Ambiguous/Changed, Green: Dominant Yes, Red: Dominant No)

In Fig. 10 showed that Campbell Harvey of Duke Univ. was the most vocal and/or cited by other, followed by James Mackintosh of WSJ. Uniquely, Harvey and Mackintosh did not participate in the 1st discourses period (Fig. 7). While Harvey had ambiguous statements (Argued Yes \& No), Mackintosh had Yes argument in Y2019, but then changed to No in Y2020. This figure covered 25.7\% of conversation and more of them argued No, followed by Ambiguous/Changed. 


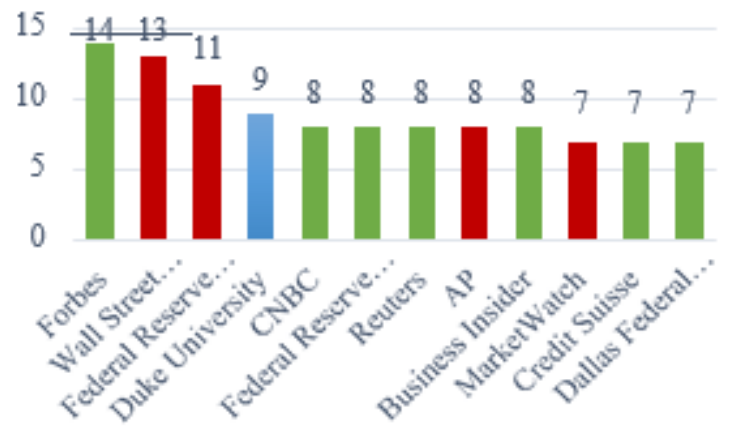

Figure 11. Organizations that Most Frequent to Discuss (Colored argument, Blue: Ambiguous/Changed, Green: Dominant Yes, Red: Dominant No)

In terms of organization, three most frequent that discussed IYC were Forbes, Wall Street Journal, and Federal Reserve Board. Shown in Figure 10, that covers 31.6\% of conversation, the 'Yes' argument more dominant than "No'. It was quite different than the view from actors. Although this view was only a fraction from the whole conversation, it reflected that the argument is quite diverse even among actors in the same organization.

Table 2. Amount of 'Yes' and 'No' Arguments Through Time

$\begin{array}{llcc}\text { Time } & \text { Calendar } & \text { Yes } & \text { No } \\ \text { Full period } & 3 / 28 / 2018-3 / 08 / 2020 & 169 & 173 \\ \text { First year } & 3 / 28 / 2018-3 / 28 / 2019 & 50 & 49 \\ \text { Second year } & 3 / 28 / 2019-3 / 08 / 2020 & 119 & 124 \\ \text { Period 1 } & 3 / 28 / 2018-12 / 09 / 2018 & 30 & 23 \\ \text { Period 2 } & 12 / 09 / 2018-08 / 17 / 2019 & 66 & 48 \\ \text { Period 3 } & 8 / 17 / 2019-3 / 08 / 2020 & 73 & 102\end{array}$

As we can see at table 2, 'Yes'- 'No' argument at full period were almost equal. But it went on different story, at Period 1 more actors agreed that IYC were a reliable predictor, then they doubled at Period 2. However, the 'No' argument grew almost tripled and flipped the conversation. What was happened should be analyzed through each concept.

The concept that held most cited at Period 1 was that 'There are evidence for inversion as a recession forecasting' and 'There are some time and ways to respond after inversion'. 12 actors put emphasized on the history data that showed only one of ten that inversion exposed false alarm. Also 12 actors believed that recession is coming in the way, but as the history data presented, the timing is somehow uncertain. there are about 15 to 24 months to take before recession is out. Hence, these actors believe there are time to respond to reduce, halt, or even stop the upcoming economic slowdown. As conclusion, at Period 1 most informant in the discourse were acknowledged the association between inverted yield curve and recession. 


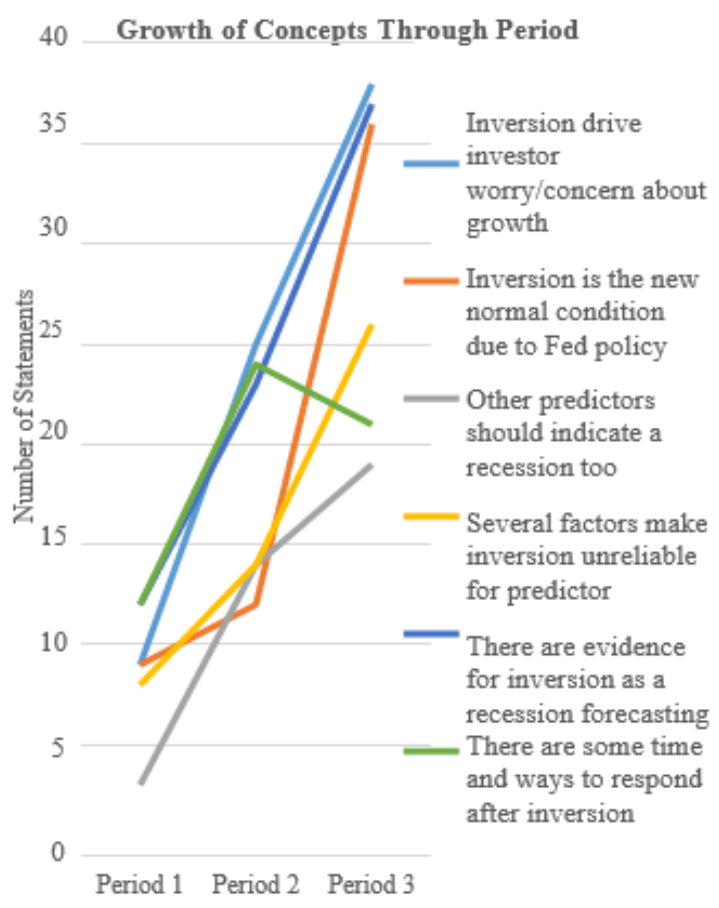

Figure 12. Growth of Concepts Through Period

In Period 2, the 'Yes' argument was still dominant, mainly many actors still believed on both concept that 'There are evidence for inversion as a recession forecasting' and 'There are some time and ways to respond after inversion'. Both arguments were doubled in number due to more actors realized that IYC had arisen more often. Consequently, the conversation was heightened. But more actors became worried as they concerned about the correlation on real economy. Hence the concept 'Inversion drive investor worry/concern about growth' became dominant.

In Period 3, the discourse much crowded than before as more actors joined conversation. The disagreement among them also intensified as the red line on Figure 8 branch out more than the green line, hence the 'No' argument became the dominant opinion and shifted the entire conversation. Almost all concepts were growing except the concept 'There are some time and ways to respond after inversion'. This concept fell in number partly due to The Federal Reserve interference and the increasing frequency of IYC emergence.

The intervention of Federal Reserve is expected by market stakeholders to ease pressure in the short-term market such as cut the interest rate or through quantitative easing by poured the market more money out hence will revert the yield curve back to normal. This stance can be possible since the Federal Reserve switch their perspective from neglecting to considering the inversion of yield curve. Research from Bauer and Mertens (2018) has been quoted by many of whom that believed in recession prediction from inversion. The Federal Reserve itself already respond to the inversion by cut back interest rate several times until the reversion is appeared. This situation then pushes the discourse into skepticism of IYC reliability, hence the concept 'Inversion is the new normal condition due to The Fed policy' as well as 'Several factors make inversion unreliable for predictor' has jumped into higher opinion. 
Therefore, the nature of discourse of IYC can be concluded that market stakeholders still see IYC as a predictor, but as Central Bank are able to intervene, the curve is easily distorted thus become more unreliable. Consequently, the next recession or crisis will be harder to predict.

How is possible that the emergence of inverted yield curve will affect the financial market? Hypothetically, if we assume that market is rational, the anxious or unattached investors will draw their money from the short-term market to the long-term market with cautious move, as such the market will be influenced in short period. The rational investor believe that the rate will be normalized by The Federal Reserve. On the other hand, irrational investor will cause the market to move more extreme as they believe the recession is incoming. Thus, potentially will draw more money in short period but cause more investors to involve, hence the stock downfall will be longer.

To examine those two arguments, the research conducts two analysis. At first, Graph analysis is used to observe any potential stock movement after IYC emerged. In Fig. 13, it showed that after IYC arisen, stock market would fall as Dow Jones Index down $-3.05 \%$, NASDAQ down $-2.93 \%$, and S\&P 500 down $-3.02 \%$ as well in period 1 , but the market will rebound eventually.

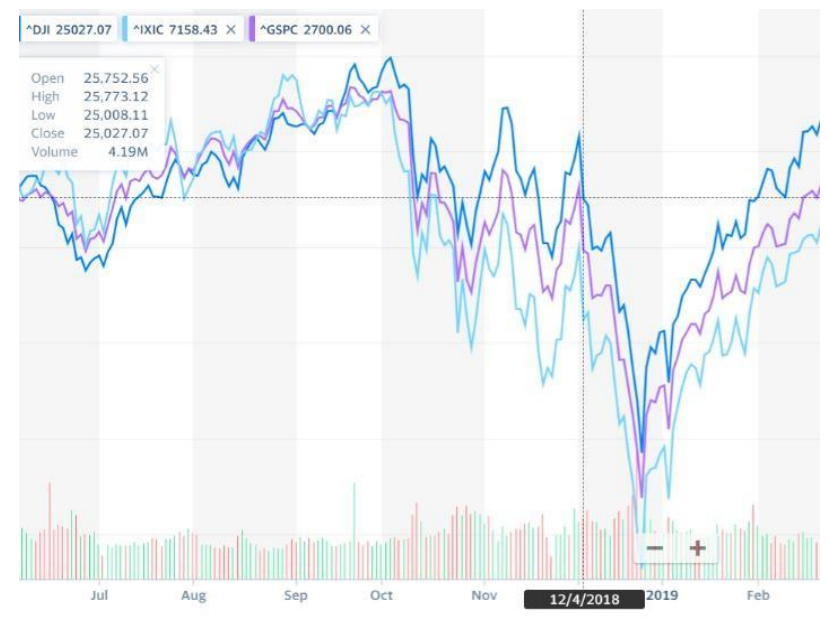

Figure 13. Stock Movement at Response to Emergence of IYC in Period 1 Source: finance.yahoo.com

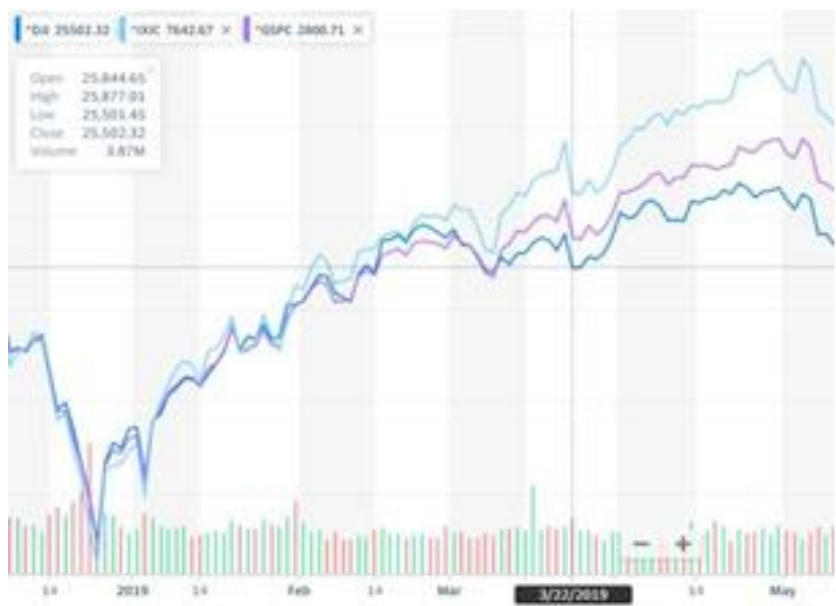

Figure 14. Stock Movement at Response to Emergence of IYC in Period 2 Source: finance.yahoo.com 


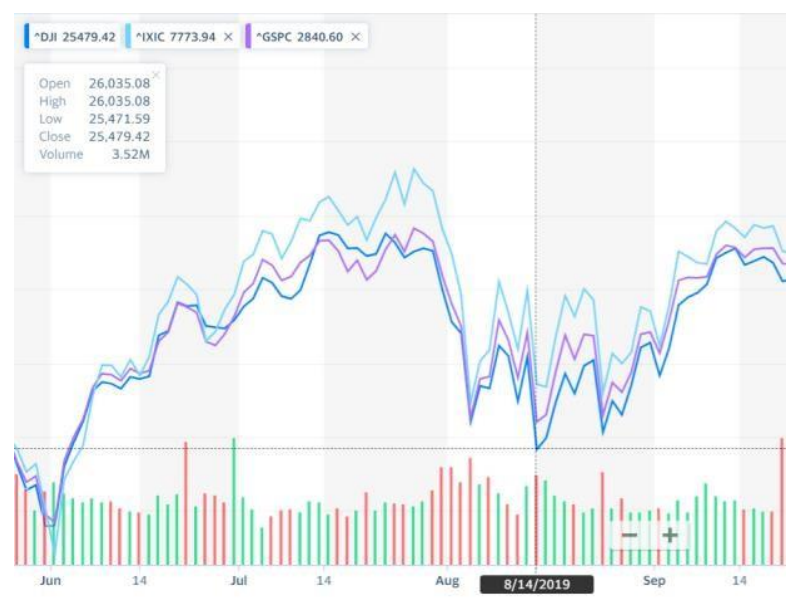

Figure 15. Stock Movement at Response to Emergence of IYC in Period 3 Source: finance.yahoo.com

Such short movement as a response of arisen inverted yield curve also seen in Period 2 and 3, but the quick rebound in shorter time is observed, rather than at Period 1 which market had bottomed first. This observation is coherence with network analysis that investors are still worried about IYC but also thought that they can respond.

The quick analysis from data visual is explained further through statistical analysis using paired sample T-Test (at 95\% in confidence level) for an observation period of 10-day stock market price change before and after IYC emerged. Each sample of Dow Jones (^DJI), NASDAQ $\left({ }^{\wedge} \mathrm{GSPC}\right)$, and S\&P500 (^IXIC) stock indices is tested using Kolmogorov-Smirnov and resulted in normal data (table $3)$.

Table 3. Normality Test using Kolmogorov Smirnov (KS Test)

\begin{tabular}{|c|c|c|c|}
\hline & \multicolumn{3}{|c|}{ Period 1} \\
\hline KS Test & ${ }^{\wedge} \mathrm{DJI}$ & ${ }^{\wedge} \mathrm{GSPC}$ & ${ }^{\wedge} \mathrm{XXIC}$ \\
\hline N Sample & 20 & 20 & 20 \\
\hline Mean & -0.0034348 & -0.003498 & -0.003143 \\
\hline St. Deviation & 0.0144765 & 0.0141552 & 0.0182199 \\
\hline KS Calculated & 0.1265909 & 0.1497057 & 0.1143917 \\
\hline \multirow[t]{3}{*}{ KS Table } & 0.3041052 & 0.3041052 & 0.3041052 \\
\hline & Normal & Normal & Normal \\
\hline & \multicolumn{3}{|c|}{ Period 2} \\
\hline KS Test & ${ }^{\wedge} \mathrm{DJI}$ & ${ }^{\wedge} \mathrm{GSPC}$ & ${ }^{\wedge} \mathrm{IXIC}$ \\
\hline N Sample & 20 & 20 & 20 \\
\hline Mean & 0.0017799 & 0,0023453 & 0.0031161 \\
\hline St. Deviation & 0.0065903 & 0.0071354 & 0.0090568 \\
\hline KS Calculated & 0.2919925 & 0.2151902 & 0.2438293 \\
\hline \multirow[t]{3}{*}{ KS Table } & 0.3041052 & 0.3041052 & 0.3041052 \\
\hline & Normal & Normal & Normal \\
\hline & \multicolumn{3}{|c|}{ Period 3} \\
\hline KS Test & ${ }^{\wedge} \mathrm{DJI}$ & ${ }^{\wedge} \mathrm{GSPC}$ & ${ }^{\wedge}|X| C$ \\
\hline N Sample & 20 & 20 & 20 \\
\hline Mean & -0.0025821 & -0.002342 & -0.002636 \\
\hline St. Deviation & 0.014129 & 0.0147432 & 0.0168213 \\
\hline KS Calculated & 0.1964348 & 0.231127 & 0.2415586 \\
\hline KS Table & 0.3041052 & 0.3041052 & 0.3041052 \\
\hline & Normal & Normal & Normal \\
\hline
\end{tabular}


Table 4. t-Test: Paired Two Sample for Means Period 1

\begin{tabular}{|c|c|c|c|c|c|c|}
\hline & \multicolumn{2}{|c|}{ ^DJI } & \multicolumn{2}{|c|}{${ }^{\wedge} \mathrm{GSPC}$} & \multicolumn{2}{|c|}{ ^IXIC } \\
\hline & Variable 1 & Variable 2 & Variable 1 & Variable 2 & Variable 1 & Variable 2 \\
\hline Mean & 0.0017041 & -0.008574 & 0.0020391 & -0.009036 & 0.0027817 & -0.009068 \\
\hline Variance & 0.0001999 & 0.0001839 & 0.0001764 & 0.0001784 & 0.0003142 & 0.0003086 \\
\hline Observations & 10 & 10 & 10 & 10 & 10 & 10 \\
\hline Pearson Correlation & 0.3780912 & & 0.343448 & & 0.3145675 & \\
\hline Hypothesized Mean & & & & & & \\
\hline Difference & 0 & & 0 & & 0 & \\
\hline df & 9 & & 9 & & 9 & \\
\hline t Stat & 2.1033223 & & 2.2943812 & & 1.813681 & \\
\hline$P(T<=t)$ one-tail & 0.0323841 & & 0.0237167 & & 0.0515657 & \\
\hline t Critical one-tail & 1.8331129 & & 1.8331129 & & 1.8331129 & \\
\hline$P(T<=t)$ two-tail & 0.0647681 & & 0.0474335 & & 0.1031315 & \\
\hline t Critical two-tail & 2.2621572 & & 2.2621572 & & 2.2621572 & \\
\hline
\end{tabular}

\begin{tabular}{|c|c|c|c|c|c|c|}
\hline & \multicolumn{2}{|c|}{${ }^{\wedge} \mathrm{DJI}$} & \multicolumn{2}{|c|}{${ }^{\wedge} \mathrm{GSPC}$} & \multicolumn{2}{|c|}{$\stackrel{\wedge}{\mathrm{XIC}}$} \\
\hline & Variable 1 & Variable 2 & Variable 1 & Variable 2 & Variable 1 & Variable 2 \\
\hline Mean & 0.001915 & 0.001645 & 0.003804 & 0.000887 & 0.005510 & 0.000722 \\
\hline Variance & 0.000024 & 0.000068 & 0.000033 & 0.000070 & 0.000050 & 0.000110 \\
\hline Observations & 10 & 10 & 10 & 10 & 10 & 10 \\
\hline $\begin{array}{l}\text { Pearson } \\
\text { Correlation }\end{array}$ & 0.241249 & & 0.168871 & & 0.114454 & \\
\hline $\begin{array}{l}\text { Hypothesized } \\
\text { Mean Difference }\end{array}$ & 0 & & 0 & & 0 & \\
\hline df & 9 & & 9 & & 9 & \\
\hline t Stat & 0.100392 & & 0.99156 & & 1.2645 & \\
\hline$P(T<=t)$ one-tail & 0.461117 & & 0.17366 & & 0.118907 & \\
\hline t Critical one-tail & 1.833113 & & 1.833113 & & 1.833113 & \\
\hline$P(T<=t)$ two-tail & 0.922234 & & 0.347321 & & 0.237813 & \\
\hline t Critical two-tail & 2.262157 & & 2.262157 & & 2.262157 & \\
\hline
\end{tabular}

\begin{tabular}{|c|c|c|c|c|c|c|}
\hline & \multicolumn{2}{|c|}{ ^DJI } & \multicolumn{2}{|c|}{${ }^{\wedge} \mathrm{GSPC}$} & \multicolumn{2}{|c|}{ IIXIC } \\
\hline & Variable 1 & Variable 2 & Variable 1 & Variable 2 & Variable 1 & Variable 2 \\
\hline Mean & -0.003337 & -0.001827 & -0.00282 & -0.001864 & -0.003012 & -0.00226 \\
\hline Variance & 0.000201 & 0.00022 & 0.000223 & 0.000235 & 0.000314 & 0.000283 \\
\hline Observations & 10 & 10 & 10 & 10 & 10 & 10 \\
\hline Pearson & & & & & & \\
\hline Correlation & -0.136413 & & -0.164746 & & -0.170801 & \\
\hline Hypothesized & & & & & & \\
\hline Mean Difference & 0 & & 0 & & 0 & \\
\hline df & 9 & & 9 & & 9 & \\
\hline t Stat & -0.21859 & & -0.130895 & & -0.089988 & \\
\hline $\mathrm{P}(\mathrm{T}<=\mathrm{t})$ one-tail & 0.415923 & & 0.449369 & & 0.465134 & \\
\hline t Critical one-tail & 1.833113 & & 1.833113 & & 1.833113 & \\
\hline$P(T<=t)$ two-tail & 0.831846 & & 0.898737 & & 0.930267 & \\
\hline t Critical two-tail & 2.262157 & & 2.262157 & & 2.262157 & \\
\hline
\end{tabular}

The result of mean difference showed in Table 4. Solely in Period 1 there is a significant difference in stock price change between 10-day before IYC emerged, compare to 10-day after. While in Period 2 and 3 there is no significant in p-value. Extending to shorter term 5-days, also only in Period 1 show significant value. While in longer term such as 15-days, there is also no significant in p-value in all Period. Furthermore, in all observed data, the 10-days mean of price change tend to lower in the period after IYC emerged, compared to before.

The result indicated that the emergence of inverted yield curve only shows short and partial response in the stock market. Such response only last at least one day and does not affect for any longer than ten days, especially in Period 1, where the market dominantly believe that IYC is a reliable predictor. 
In contrast, such as in Period 3 where the market is dominantly do not believe a reliability of IYC, the stock market does not move significantly.

\section{CONCLUCION AND RECOMMENDATION}

This study proved that the cumulative market believes, or their opinion will affect to stock price movement, confirmed the informational theory of investment from (Chen, 2006). The inverted yield curve that intervened by The Federal Reserve can no longer be reliably trusted by financial market stakeholder as an indicator for recession, resulted in no significant movement of stock price change. A differential from previous period. But there is also no reason to abandon it all. As recent event show that global recession due to pandemic Covid-19 also happened after IYC emerged several times. It means, IYC might have a fundamental information as a recession predictor.

Furthermore, the research also suggest that any recession predictor is beneficial for investor to reallocate their portfolio as well as for government to design the counter-recession strategy, unfortunately such indicator only exist in advanced and efficient market. The inverted yield curve will exist in the market where high liquid money can move easily from short-term market to long-term market, as well as such information is available for anyone, anywhere, and anytime. Also, such movement reflects market anxiety, wariness, and concern.

In emerging market such as Indonesia, if some potential indicators such as Rupiah value depreciation, high capital market outflow, high current account deficit, or low investor confidence are emerged, it can cause market to worry and even to start to reallocate their fund. Research from (Rofi, 2019) showed that in the previous events Indonesia stock market had crashed fourth times with those indicators were emerged before. Although those indicators are not as unique as inverted yield curve. Hence, future research about recession indicator especially in emerging market can be beneficial for financial market stakeholders. Further research in abnormal return could also prove further the informational theory of investment. 


\section{REFERENCE}

Bauer, M. D., \& Merten, T. M. (2018). Information in the Yield Curve about Future Recession. San Francisco: Federal Reserve Bank of San Francisco Economic Letter.

Bauer, M. D., \& Mertens, T. M. (2018). Economic Forecasts with the Yield Curve. San Francisco: Federal Reserve Bank of San Francisco Economic Letter.

Bauer, M. D., \& Rudebusch, G. D. (2014). The Signaling Channel for Federal Reserve Bond Purchases. International Journal of Central Banking, 233-289.

Bloomberg. (2018). Bloomberg Opinion. Retrieved from Bloomberg: www. bloomberg.com

Bloomberg. (2019). Bloomberg Opinion. Retrieved from Bloomberg: www.bloomberg.com

Bodie, Z., Kane, A., \& Marcus, A. J. (2013). Investment. New York: McGraw-Hill Education.

Brida, J., Gomez, D. M., \& Seijas, M. (2015). Network Analysis of Returns and Volume Trading in Stock Markets: Euro Stoxx Case. SSRN.

Chen, J. (2006). The Informational Theory of Investment: A Comparison with Behavioral Theories. SSRN, 1-31. doi:https://dx.doi.org/10.2139/ssrn.380460

Creswell, J. (2009). Research Design: Qualitative, Quantitative, and Mixed Methods Approaches 3rd Edition. Thousand Oaks, CA: Sage Publications.

duQuesnay, B. (2019). The Yield Curve Inverted, but You're Telling Me This Time is Different. Retrieved from Blair Belle Curve: blairbellcurve.com

Fidelity. (2019). Are Bond Signaliung Recession?. Retrieved from Fidelity Vewpoint: www.fidelity.com

FT. (2019). Financial Times Report. Retrieved from Financial Times: www.ft.com

Holston, K., Laubach, T., \& Williams, J. (2017). Measuring the Natural Rate of Interest: International Trends and Determinants . Journal of International Economics , 39-75.

Lewis, A. (2019). The Inverted Yield Curve Explained and What it Means for Your Money. Retrieved from CNBC: www.cnbc.com

Madura, J. (2017). International Financial Management (13th ed.). Boston, USA: South-Western College Pub/Cengage Learning.

Marquit, M. (2019). Best Investment News Websites: Stock Investing News \& Analysis. Retrieved from Consumerism Commentary. https://www.consumerismcommentary.co m/best-investment-newswebsites-stock- investing-news-analysis/ 
Rofi, M.A. (2021). Discourses of Inverted Yield Curve and the Reaction ....

Marte, J. (2019). Recession Watch: What is An Inverted Yield Curve and Why Does it Matter? Retrieved from The Washington Post: www.washingtonpost.com

Minjun, K., \& Sayama, H. (2017). Predicting stock market movements using network science: an information theoretic approach. Applied Network Science, 1-14. doi:DOI: 10.1007/s41109-0170055-y

Nations, S. (2017). A History of United States in Five Crashes: Stock Market Meltdowns that Defined a Nation. New York: HarperCollins Publishers.

OMahony, P. (2019). Should Markets Panic Over the Inverted Yield Curve?. Retrieved from Irish Times: www.irishtimes.com

Rofi, M. A. (2019). How Importance of Financial Institution in the Stock Market Network?. Jakarta: LKI Stabilitas Sistem Keuangan Bank Indonesia.

Smith, C. (2019). Why the Inverted US Yield Curve Need Not Mean a Recession is On Its Way. Retrieved from Fin24: www.fin24.com

Wu, S., Tuo, M., \& Xiong, D. (2015). Network Structure Detection and Analysis of Shanghai Stock Market. Journal of Industrial Engineering and Management.

Yoshinaga, C. E., \& Junior, F. (2012). The Relationship between Market Sentiment Index and Stock Rates of Return: A Panel Data Analysis. Brazilian Administration Review, 9, 189-210. 